\title{
Nitric Oxide Removal from Flue Gases by Carbon-enriched Coal Fly Ash
}

\author{
Begoña Rubio, Maria Teresa Izquierdo \\ Department of Energy and Environment, Instituto de Carboquimica (CSIC), Spain \\ cross $^{\text {ref }}$ http://dx.doi.org/10.5755/j01.erem.63.1.2823
}

(received in November, 2012, accepted in March, 2013)

\begin{abstract}
The aim of this work is to evaluate the characteristics of activated and non-activated carbon obtained from carbon-enriched coal fly ashes (CECFA) from two different power stations to be used in the low temperature reduction of NO from stack gases. Carbon-rich fractions were obtained by mechanical sieving of fly ashes and by oil agglomeration. Activation of some samples was carried out in steam at $900^{\circ} \mathrm{C}$ in order to develop porosity onto the samples. The obtained activated and non-activated samples were characterised by several techniques and their nitric oxide removal capacity at a low temperature using ammonia as a reducing agent was evaluated (gas conditions: $150{ }^{\circ} \mathrm{C}, 1000 \mu \mathrm{L} / \mathrm{L} \mathrm{NO}, 1200 \mu \mathrm{L} / \mathrm{L} \mathrm{NH} \mathrm{NH}_{3}, 60 \mathrm{~mL} / \mathrm{L} \mathrm{O}_{2}$, Ar as balance).

CECFA obtained only by sieving had carbon content varying from $1 \%$ to $47 \%$, and NO reduction levels varying from $3 \%$ to $29 \%$. CECFA L2A and E2A, obtained by sieving, agglomeration and further activation, contained $66 \%$ and $57 \%$ of carbon respectively, and their NO conversion was $36 \%$ and $48 \%$. BET surface areas of CECFA samples before activation were in all cases below $20 \mathrm{~m}^{2} / \mathrm{g}$. In the case of activated samples, L2A and E2A the surface area increased to 217 and $395 \mathrm{~m}^{2} / \mathrm{g}$ respectively.

In all cases, and comparing samples with the same carbon content, CECFA coming from Escucha demonstrated higher NO conversion capacity.

The obtained results show that carbon content, surface area and parent coal type are the main parameters that influence the NO removal capacity of the obtained CECFA.

Keywords: fly ash, activated carbon, nitric oxide, selective catalytic reduction.
\end{abstract}

\section{Introduction}

Nitric oxide is formed during the combustion of fossil fuel and is subsequently oxidised in the atmosphere to $\mathrm{NO}_{2}$. The increasing knowledge of pollution problems arising from NOx has led to the introduction of stringent environmental regulations concerning NOx emissions that in most cases cannot be met by the only application of combustion modifications, thus post-combustion methods have been developed. The selective catalytic reduction (SCR) is the only flue gas denitrification technique so far which has been proven to be very effective (Hjalmarsson 1990; Izquierdo and Rubio 2009; Nakajima and Hamada 1996). However, the SCR method can be improved in two aspects: lowering gas temperature (avoiding reheating) and using cheap catalysts. Activated carbons show high $\mathrm{NO} x$ removal efficiency at low temperatures $\left(100{ }^{\circ} \mathrm{C}\right.$ to $\left.250{ }^{\circ} \mathrm{C}\right)$
(Richter et al. 1990), but their cost remains a drawback. In the past decade the studies were conducted on the use of different cheap precursors for the production of carbonaceous substrates with similar performance, but not on activated carbon in the low temperature NO removal (Cha et al. 2010; Gálvez et al. 2010; Izquierdo et al. 2007).

On the other hand, the combustion modifications mentioned above involve both the lowering in furnace temperatures and the progressive injection of air to reduce the degree of nitrogen oxidation, the so-called low NOx burner. A drawback of this technology is a higher amount of unburned carbon in the resulting fly ashes (FA). FA is the main by-product of coal combustion in pulverized coal boilers and consists mainly of oxides of silica, aluminum, iron and calcium, along with some unburned or partially 
burned carbon residue (Lindon 2001; Moreno et al. 2005). Carbon has adverse effects on the use of FA for concrete industry, whereas the introduction of certain NOx control operational measures can decrease the marketability of some FA. The fate of the unburned carbon is mainly disposal, although in recent years several routes for their effective use have been proposed.

The utilization of FA as a low-cost adsorbent for various adsorption processes for removal of pollutants in air and water systems has been reviewed by Wang and $\mathrm{Wu}$ (2006) and recently by Ahmaruzzaman (2010). Most of these studies agreed that an unburned carbon component plays an important role in adsorption capacity. Unburned carbon has been tested as an adsorbent for the treatment of wastewater (Nollet et al. 2003; Rastogi et al. 2008; Wang and Viraraghavan 1998), mercury adsorption (MarotoValer et al. 2005) $\mathrm{CO}_{2}$ capture (Arenillas et al. 2005; Maroto-Valer et al. 2008) and also in $\mathrm{SO}_{2}$ removal (Davini 2002; Izquierdo and Rubio 2008).

FA have been also studied as an adsorbent in NO removal from flue gases (Lu and Do 1991; Rubel et al. 2005), but the use of unburned carbon from FA in the low temperature NO reduction has been little explored until the present time (Rubio et al. 2007).

Unburned carbon presents an advantage over other carbon precursors by requiring only an activation process, since it has already gone through a devolatilisation step during the combustion in the furnace of the power station, thus the carbonising process can be avoided.
The aim of this work is to obtain and characterise several carbon-enriched coal fly ashes (CECFA) and evaluate their performance in the low temperature reduction of $\mathrm{NO}$ with ammonia from flue gases.

\section{Methods}

\subsection{Materials}

Two FA (F type) from two pulverised-coal fired power stations were chosen as starting material (named LF and EF). The power stations are located in the north (Lada 505MW) and the east (Escucha $160 \mathrm{MW})$ of Spain. The coal burned in Lada is a bituminous one, while in Escucha a blend of $70 \%$ of lignite and $30 \%$ of bituminous coal is used. These FA are produced in full-scale boilers under, what can be considered, typical utility operating conditions. Approximately $150 \mathrm{~kg}$ of FA were fractionated by standard dry-sieving techniques.

A preliminary FA screening was performed on each sample. In this way, six fractions were obtained: $<100 \mu \mathrm{m}, 100 \mu \mathrm{m}-200 \mu \mathrm{m}, 200 \mu \mathrm{m}-300 \mu \mathrm{m}, 300 \mu \mathrm{m}$ $-400 \mu \mathrm{m}, 400 \mu \mathrm{m}-500 \mu \mathrm{m}$ and $>500 \mu \mathrm{m}$. Each collected fraction was weighed and their carbon content was determined. Table 1 shows mass fraction distribution in fractions and carbon content of each fraction.

Carbon distribution in recovered sieved fractions

\begin{tabular}{||l|c|c|c|c|c|c|c||}
\hline \multicolumn{2}{||c|}{} & $<\mathbf{1 0 0} \boldsymbol{\mu m}$ & $\mathbf{1 0 0 - 2 0 0} \boldsymbol{\mu m}$ & $\mathbf{2 0 0 - 3 0 0} \boldsymbol{\mu m}$ & $\mathbf{3 0 0 - 4 0 0} \boldsymbol{\mu m}$ & $\mathbf{4 0 0 - 5 0 0} \boldsymbol{\mu m}$ & $>\mathbf{5 0 0} \boldsymbol{\mu m}$ \\
\hline Lada & $w \times 100$ & 95.00 & 4.67 & 0.23 & 0.06 & 0.02 & 0.02 \\
& $w_{C} \times 100$ & 7.05 & 46.95 & 35.54 & 25.80 & 29.42 & 25.36 \\
\hline \multirow{2}{*}{ Escucha } & $w \times 100$ & 87.60 & 10.20 & 1.55 & 0.40 & 0.12 & 0.13 \\
& $w_{C} \times 100$ & 1.08 & 7.00 & 14.02 & 25.33 & 27.60 & 24.27 \\
\hline
\end{tabular}

The information obtained in this preliminary study was used to determine the optimum particle size to obtain CECFA as a function of weight percentage and unburned coal content. Following this procedure, two CECFAs were obtained with different particle

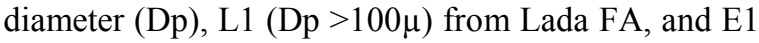
$(\mathrm{D} p>200 \mu \mathrm{m})$ from Escucha FA. A part of samples L1 and E1 was used as the feed for a subsequent oil agglomeration to further increase their carbon content. The oil agglomeration was performed in the Waring blender equipment (Alonso et al. 1999). In a typical experiment, $400 \mathrm{~cm}^{3}$ of distilled water and $16 \mathrm{~g}$ of sample were placed in the blender and mixed at $11,000 \mathrm{rpm}$ for $5 \mathrm{~min}$, to disperse the particles. Then, $2 \%$ of vegetable oil (soya bean frying oil) was added, and mixing was continued at the same speed for $60 \mathrm{~s}$ to produce agglomerates. After recovery, the agglomerates were filtered, washed with ethanol, perchloroethylene and ethyl ether to extract the oil. The agglomerates were then washed with water and dried overnight at $50{ }^{\circ} \mathrm{C}$. Thus, two samples, namely L2 and E2, were obtained.
These samples and their parent samples L1 and E1 were activated with steam in a fluidised bed at 900 ${ }^{\circ} \mathrm{C}$ for $2 \mathrm{~h}$. After this period of time the steam flow was cut off and switched by the nitrogen flow until the room temperature was reached. Activated CECFAs were named L1A, E1A, L2A, E2A.

The origin and treatment of all samples studied can be seen in Figure 1.

\subsection{Characterisation}

Ash content of the samples was determined according to standard ISO-1171-1976. Elemental analysis was carried out in an apparatus CARLO ERBA 1108 to determine C, H, N and S content.

The composition of ashes was determined by inductively coupled plasma (ICP-AES) in an apparatus JY 2000 ULTRATRACE on a dissolution coming from the digestion by $\mathrm{LiB}_{4}$ and further $\mathrm{HCl}$ attack of samples. 
Textural characterization was performed by $\mathrm{N}_{2}$ adsorption. Nitrogen adsorption/desorption isotherms at $-196{ }^{\circ} \mathrm{C}$ were obtained in an apparatus AS-1 from Quantachrome. Prior to the analysis, samples were outgassed at $250{ }^{\circ} \mathrm{C}$ up to a vacuum of $10^{-5} \mathrm{~mm} \mathrm{Hg}$. Brunauer-Emmet-Teller (BET) equation was used to determine the surface area of the samples.

\subsection{NO experiments}

An experimental installation described in detail elsewhere (Izquierdo and Rubio 2008) was used to test NO removal capacity of samples in conditions of the selective catalytic reduction (SCR) reaction, using ammonia as a reducing agent.

The installation consists of a fixed bed reactor, devices for the preparation of gas mixtures, temperature control and on-line analysis of the concentration of the gas stream. A flow of $25 \mathrm{~mL} / \mathrm{min}$ of gas containing $1000 \mu \mathrm{L} / \mathrm{L} \mathrm{NO}, 1200 \mu \mathrm{L} / \mathrm{L} \mathrm{NH}_{3}, 60$ $\mathrm{mL} / \mathrm{L} \mathrm{O}_{2}$ and $\mathrm{Ar}$ as balance was passed through a bed of $2 \mathrm{~g}$ of sample at $150{ }^{\circ} \mathrm{C}$. $\mathrm{NO}, \mathrm{NH}_{3}, \mathrm{O}_{2}$ and Ar were dosed from gas cylinders $(99,9990 \%$ of quality, from Air Liquide) and their flow was maintained using mass flow controllers from Brucker. The concentration of each gas was measured by mass spectrometry in the equipment from Balzers.

The reactor was provided with a bypass which allows the measurement of the NO concentration before each experiment.

The reaction results are described in terms of NO conversion as:

$N O$ conversion $\left.=\left[N O_{\text {in }}-N O_{\text {out }}\right) / N O_{\text {in }}\right] \times 100$

where:

$\mathrm{NO}_{\text {in }}$ - inlet concentration of $\mathrm{NO}$ at each time

$\mathrm{NO}_{\text {out }}$ - outlet concentration of $\mathrm{NO}$ at each time

The amount of NO removed is calculated from the integration of conversion-time curves.
Selectivity to $\mathrm{N}_{2}$ was calculated according to:

Selectivity to $\mathrm{N}_{2}=\mathrm{N}_{2 \text { out }} x 100 /\left(\mathrm{N}_{2 \text { out }}+\mathrm{N}_{2} \mathrm{O}_{\text {out }}\right)$

where:

$\mathrm{N}_{\text {2out }}$ - outlet concentration of $\mathrm{N}_{2}$ at each time

$\mathrm{N}_{2} \mathrm{O}_{\text {out }}$ - outlet concentration of $\mathrm{N}_{2} \mathrm{O}$ at each time

No $\mathrm{N}_{2} \mathrm{O}$ was detected at the outlet of the reactor once the steady state was reached.

In presence of $\mathrm{O}_{2}$, and under the studied conditions $90 \mu \mathrm{L} / \mathrm{L}-100 \mu \mathrm{L} / \mathrm{L}$ of the inlet $\mathrm{NO}$ is oxidized to $\mathrm{NO}_{2}$. The concentration of this $\mathrm{NO}_{2}$ was followed also by mass spectrometry.

Some of the experiments were duplicated and once the stationary state was reached the conversion value varied in \pm 1

\section{Results and discussion}

\subsection{Characterisation}

FA from Lada (LF) contains a significantly higher amount of unburned coal than those from Escucha (EF). The results of previous size screening indicate that in Escucha FA, the unburned coal is present in coarser particles than in Lada FA. For this reason the bulk of Lada FA was finally sieved at 100 $\mu \mathrm{m}$ (sample L1), whereas FA from Escucha was sieved at $200 \mu \mathrm{m}$ (sample L2). In this way, a sufficient amount of material was collected from the two fly ashes for performing the oil agglomeration step to increase the carbon content of these fractions. The history of samples can be seen in Figure 1.

From XRD characterisation (Rubio et al. 2008) major mineral phases in both LF and EF were quartz, mullite and aluminosilicate glass. Escucha FA (EF) also contain significant amounts of maghemite.

The ash composition of samples obtained by sieving is shown in Table 2.

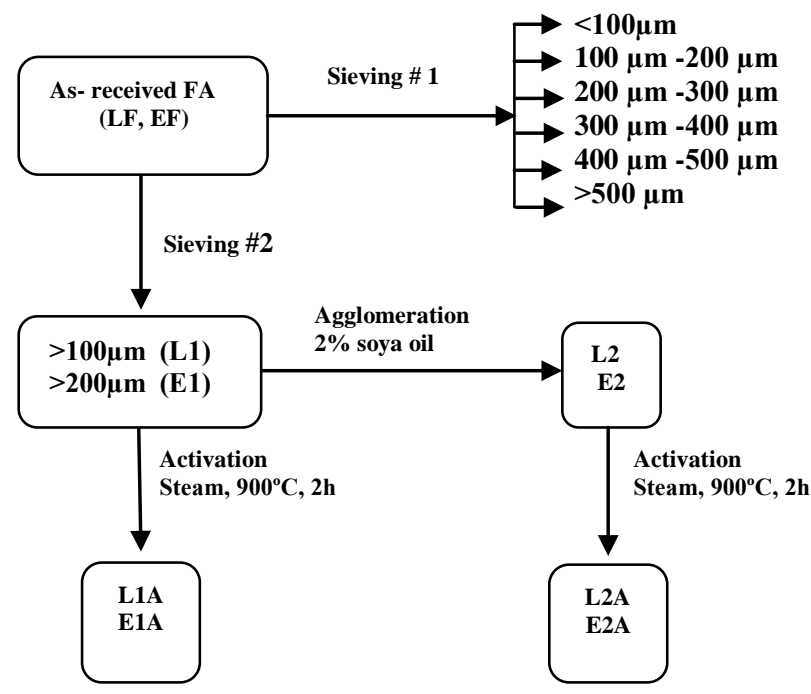

Fig. 1. Origin and treatment of the samples 
Table 2. $\quad$ Ash composition of the fractions obtained by sieving, expressed as main metal oxides (\%) obtained by ICP

\begin{tabular}{||l|l|c|c|c|c|c|c|c|c||}
\hline \multirow{3}{*}{ Sample } & \multirow{2}{*}{$\begin{array}{c}\text { Particle diameter } \\
(\boldsymbol{\mu m})\end{array}$} & \multicolumn{9}{|c|}{$\boldsymbol{w}_{\mathbf{M x O y}} \mathbf{x} \mathbf{1 0 0}$} \\
\cline { 3 - 9 } & $\mathrm{SiO}_{2}$ & $\mathrm{Al}_{2} \mathrm{O}_{3}$ & $\mathrm{CaO}$ & $\mathrm{Fe}_{2} \mathrm{O}_{3}$ & $\mathrm{~K}_{2} \mathrm{O}$ & $\mathrm{MgO}$ & $\mathrm{Na}_{2} \mathrm{O}$ & $\mathrm{TiO}_{2}$ \\
\hline \multirow{4}{*}{$\mathrm{LF}$} & 100 & 52.11 & 33.07 & 5.23 & 3.29 & 0.49 & 1.10 & 0.80 & 1.80 \\
& $100-200$ & 56.48 & 29.92 & 4.69 & 3.08 & 0.71 & 0.89 & 0.04 & 1.42 \\
& $200-300$ & 56.60 & 30.15 & 4.67 & 3.09 & 0.89 & 0.90 & 0.04 & 1.29 \\
& $300-400$ & 57.30 & 29.95 & 5.89 & 4.21 & 0.66 & 1.08 & 0.09 & 1.59 \\
& $400-500$ & 52.89 & 30.81 & 6.02 & 4.43 & 0.80 & 1.08 & 0.07 & 1.63 \\
& $>500$ & 53.99 & 31.29 & 5.89 & 4.37 & 0.64 & 1.11 & 0.08 & 1.66 \\
\hline \multirow{5}{*}{$\mathrm{EF}$} & $<100$ & 46.21 & 26.40 & 6.07 & 16.73 & 1.63 & 1.39 & 0.22 & 0.96 \\
& $100-200$ & 47.77 & 25.70 & 5.25 & 15.77 & 1.56 & 1.20 & 0.18 & 0.81 \\
& $200-300$ & 49.88 & 26.88 & 4.91 & 14.65 & 1.66 & 1.21 & 0.19 & 0.81 \\
& $300-400$ & 49.31 & 26.19 & 5.24 & 15.91 & 1.61 & 1.23 & 0.19 & 0.85 \\
& $400-500$ & 47.44 & 24.29 & 5.73 & 18.45 & 1.55 & 1.26 & 0.16 & 0.81 \\
& $>500$ & 45.34 & 23.59 & 5.86 & 18.37 & 1.40 & 1.21 & 0.18 & 0.77 \\
\hline \hline
\end{tabular}

FA chemical composition varies depending upon the type of coal used, combustion conditions and air pollution control devices. The two fly ash types studied in this work are of $\mathrm{F}$ class (mass fraction of $\mathrm{SiO}_{2}+\mathrm{Al}_{2} \mathrm{O}_{3}+\mathrm{Fe}_{2} \mathrm{O}_{3}>70 \%$, mass fraction of $\mathrm{CaO}<$ $5 \%)$.

From data given in Table 2, it can be deduced that in general the granulometric separation does not involve a segregation of inorganic species, an exception is $\mathrm{Ca}$ and $\mathrm{Fe}$ compounds. An increase in these oxides is observed in their coarser fractions.

The chemical composition of the agglomerated and activated samples is given in Table 3 . In this case, the agglomeration and activation process produces a decrease in calcium and iron content of the samples.
This effect is noteworthy in the case of Escucha samples. The technique of oil agglomeration employs the difference in surface properties of unburned carbon and the inorganic part of FA. The unburned carbon particles are hydrophobic and are preferentially wet by oil, and the hydrophilic mineral matter is retained in an aqueous phase. In view of the results obtained by ICP, it can be deduced that ironcontaining compounds in the studied FA are in the form of discrete particles or in carbonaceous particles with a high inorganic content and have been retained in anaqueous phase. Moreover, high specific gravity of maghemite $\left(4.9 \mathrm{~g} / \mathrm{cm}^{3}\right)$ can lead to these particles being rejected.

Table 3.

Ash composition of raw and treated samples expressed as main metal oxides obtained by ICP

\begin{tabular}{||l|c|c|c|c|c|c|c|c||}
\hline \multirow{2}{*}{ Sample } & \multicolumn{10}{|c|}{$\boldsymbol{w}_{\mathbf{M x O y}} \mathbf{x} \mathbf{1 0 0}$} \\
\cline { 2 - 9 } & $\mathbf{S i O}_{\mathbf{2}}$ & $\mathbf{A l}_{\mathbf{2}} \mathbf{O}_{\mathbf{3}}$ & $\mathbf{C a O}$ & $\mathbf{F e}_{\mathbf{2}} \mathbf{O}_{\mathbf{3}}$ & $\mathbf{K}_{\mathbf{2}} \mathbf{O}$ & $\mathbf{M g O}$ & $\mathbf{N a}_{2} \mathbf{O}$ & $\mathbf{T i O}_{\mathbf{2}}$ \\
\hline LF & 52.95 & 33.97 & 5.29 & 3.26 & 0.46 & 1.08 & 0.03 & 1.82 \\
L1 & 55.70 & 31.65 & 5.86 & 3.18 & 0.45 & 0.96 & 0.07 & 1.60 \\
L1A & 53.00 & 30.23 & 4.47 & 3.25 & 0.42 & 0.80 & 0.03 & 1.36 \\
L2 & 53.80 & 34.78 & 2.97 & 1.41 & 0.54 & 0.57 & 0.08 & 1.01 \\
L2A & 52.92 & 35.65 & 2.34 & 2.42 & 0.56 & 0.52 & 0.03 & 1.33 \\
& & & & & & & & \\
\hline EF & 47.33 & 26.95 & 5.17 & 15.32 & 1.71 & 1.31 & 0.21 & 0.88 \\
E1 & 49.56 & 27.47 & 4.80 & 13.20 & 1.76 & 1.24 & 0.19 & 0.85 \\
E1A & 50.46 & 27.09 & 4.06 & 12.04 & 1.65 & 1.11 & 0.17 & 0.94 \\
E2 & 50.86 & 31.22 & 3.66 & 7.09 & 1.15 & 1.17 & 0.20 & 1.10 \\
E2A & 50.45 & 34.76 & 2.66 & 4.80 & 0.99 & 1.04 & 0.14 & 1.31 \\
\hline \hline
\end{tabular}

The elemental analysis and ash content of the fractions obtained by sieving are shown in Table 4.

The distribution of unburned coal according to the particle size differs greatly if both fly ashes are compared. Only fractions of particle size $>400 \mu$ are similar. The fraction of particle size between $100 \mu$ and $200 \mu$ of Lada FA contains a higher amount of unburned coal, as its carbon content has revealed. However, the carbon content of the Escucha fraction of the same particle size is very low - only a mass fraction of $7 \%$.

A very low hydrogen content of the samples, particularly in Escucha samples, indicates a high degree of condensation, as corresponds to a partially burned coal. Fractions from Escucha FA contain a slightly higher amount of sulphur than those from Lada. A nitrogen content is similar in both fly ashes. 
Table 4.

Elemental analysis and ash content of the fractions obtained by sieving

\begin{tabular}{|c|c|c|c|c|c|c|c|c|c|c|c|}
\hline \multirow{2}{*}{ Sample } & \multirow{2}{*}{$\begin{array}{c}\text { Particle } \\
\text { diameter } \\
(\mu \mathrm{m})\end{array}$} & \multicolumn{4}{|c|}{$\bar{w} \boldsymbol{w} \times 100^{\mathbf{a}}$} & \multirow{2}{*}{ Sample } & \multirow{2}{*}{$\begin{array}{c}\text { Particle } \\
\text { Diameter } \\
(\mu \mathrm{m})\end{array}$} & \multicolumn{4}{|c|}{$\bar{w} \boldsymbol{w} \times 100^{\mathbf{a}}$} \\
\hline & & $\mathrm{C}$ & $\mathrm{H}$ & $\mathrm{N}$ & Ash & & & $\mathrm{C}$ & $\mathrm{H}$ & $\mathrm{N}$ & Ash \\
\hline \multirow{6}{*}{$\mathrm{LF}$} & $<100$ & 7.03 & 0.08 & 0.07 & 93.4 & \multirow{6}{*}{$\mathrm{EF}$} & & 1.08 & 0.00 & 0.00 & 98.90 \\
\hline & $100-200$ & 46.95 & 0.09 & 0.47 & 53.2 & & $<100$ & 7.00 & 0.05 & 0.10 & 93.53 \\
\hline & $200-300$ & 35.54 & 0.10 & 0.39 & 63.7 & & $100-200$ & 14.02 & 0.05 & 0.17 & 84.38 \\
\hline & $300-400$ & 25.79 & 0.21 & 0.29 & 73.1 & & $200-300$ & 25.33 & 0.08 & 0.30 & 72.19 \\
\hline & $400-500$ & 29.42 & 0.20 & 0.36 & 69.3 & & $300-400$ & 27.60 & 0.07 & 0.34 & 68.64 \\
\hline & $>500$ & 25.36 & 0.70 & 0.33 & 72.3 & & $\begin{array}{l}400-500 \\
>500\end{array}$ & 24.27 & 0.10 & 0.32 & 73.77 \\
\hline
\end{tabular}

Elemental analysis and ash content of agglomerated and activated samples can be seen in Table 5.

E1 y L1 are the fractions obtained by sieving. The carbon content of E1 is only $12.3 \%$, therefore additional methods of carbon concentration are mandatory in the case of Escucha FA. Oil agglomeration increases the carbon content remarkably in both FA fractions. This increase is very significant for Escucha samples as the carbon content in E1 fraction is raised from $12.30 \%$ to $64.08 \%$.

The carbon content of Escucha samples is in all cases lower than that of Lada samples, but the difference in carbon content of activated samples L1A and E1A is very significant. This is due to two reasons: i) the carbon content of E1A precursor E1 is much lower than that of L1A precursor L1, and ii) the sample E1 is more reactive than L1 and their burn off during the activation process is higher. Similar behaviour is observed comparing activated samples E2A and L2A. This higher reactivity of Escucha samples is confirmed by TG experiments (Rubio et al. 2008) and can be attributable to their rank (a lignitesubbituminous blend is burned in Escucha, whereas anthracite is burned in Lada) and also to their higher content in several metallic species ( $\mathrm{Na}, \mathrm{K}, \mathrm{Fe}, \mathrm{Ca})$, which can act as catalyst in the activation process (Domazetis et al. 2008; Yu et al. 2006).

Table 5.

Elemental analysis and ash content of raw and treated samples

\begin{tabular}{|c|c|c|c|c|c|c|c|c|c|c|c||}
\hline \multirow{2}{*}{ Sample } & \multicolumn{4}{|c|}{$\boldsymbol{w} \times 100^{\mathbf{a}}$} & \multicolumn{5}{|c|}{$\boldsymbol{w} \times 100^{\mathbf{a}}$} \\
\cline { 2 - 7 } & $\mathrm{C}$ & $\mathrm{H}$ & $\mathrm{N}$ & $\mathrm{S}$ & Ash & & $\mathrm{C}$ & $\mathrm{H}$ & $\mathrm{N}$ & $\mathrm{S}$ & Ash \\
\hline LF & 7,55 & 0,14 & 0,09 & 0,02 & 94.19 & EF & 2.10 & 0.01 & 0.00 & 0.26 & 98.21 \\
L1 & 25.98 & 0.08 & 0.28 & 0.19 & 65.50 & E1 & 12.30 & 0.03 & 0.15 & 0.23 & 79.56 \\
L1A & 24.02 & 0.07 & 0.27 & 0.18 & 74.10 & E1A & 6.05 & 0.07 & 0.00 & 0.05 & 91.50 \\
L2 & 68.39 & 0.35 & 0.61 & 0.41 & 26.00 & E2 & 64.08 & 0.46 & 0.76 & 0.39 & 31.28 \\
L2A & 66.27 & 0.20 & 0.72 & 0.43 & 31.29 & E2A & 57.62 & 0.21 & 0.71 & 0.12 & 41.15 \\
\hline
\end{tabular}

Carbon from class $\mathrm{F}$ ashes has surface areas which are typically in the range of about $30-70 \mathrm{~m}^{2} / \mathrm{g}$. The surface areas obtained for the samples studied in this work are shown in Table 6. The surface areas of size separated fractions oscillate between 2 and 18 $\mathrm{m}^{2} / \mathrm{g}$. These areas are attributable to the carbonaceous component of the samples, since the surface area of the inorganic fraction contributes only $07-08 \mathrm{~m}^{2} / \mathrm{g}$ (Külaots et al. 2004), and the obtained values correlate well with the carbon content of the samples.

Table 6.

Textural data of studied samples from nitrogen adsorption

\begin{tabular}{|c|c|c|c|c|c|}
\hline Samples & $\begin{array}{c}\mathrm{S}_{\mathrm{BET}} \\
\left(\mathrm{m}^{2} / \mathrm{g}\right)\end{array}$ & $\begin{array}{c}\mathrm{Vp} / \mathrm{po}=0.99 \\
\left(\mathrm{~cm}^{3} / \mathrm{g}\right)\end{array}$ & Samples & $\begin{array}{c}\mathrm{S}_{\mathrm{BET}} \\
\left(\mathrm{m}^{2} / \mathrm{g}\right)\end{array}$ & $\begin{array}{c}\mathrm{Vp} / \mathrm{po}=0.99 \\
\left(\mathrm{~cm}^{3} / \mathrm{g}\right)\end{array}$ \\
\hline $\begin{array}{c}\text { LF } \\
\text { L1 } \\
\text { L1A } \\
\text { L2 } \\
\text { L2A }\end{array}$ & $\begin{array}{c}5 \\
19 \\
97 \\
9 \\
217\end{array}$ & $\begin{array}{l}0.014 \\
0.040 \\
0.079 \\
0.003 \\
0.170\end{array}$ & $\begin{array}{c}\text { EF } \\
\text { E1 } \\
\text { E1A } \\
\text { E2 } \\
\text { E2A }\end{array}$ & $\begin{array}{c}3 \\
13 \\
65 \\
2 \\
395\end{array}$ & $\begin{array}{l}0.002 \\
0.030 \\
0.066 \\
0.001 \\
0.290\end{array}$ \\
\hline $\begin{array}{c}\mathrm{L}<100 \mu \mathrm{m} \\
\mathrm{L} 100-200 \mu \mathrm{m} \\
\text { L } 200-300 \mu \mathrm{m} \\
\text { L } 300-400 \mu \mathrm{m} \\
\text { L } 400-500 \mu \mathrm{m} \\
\quad \mathrm{L}>500 \mu \mathrm{m}\end{array}$ & $\begin{array}{c}4 \\
18 \\
17 \\
13 \\
13 \\
11\end{array}$ & $\begin{array}{l}0.012 \\
0.030 \\
0.027 \\
0.021 \\
0.021 \\
0.018\end{array}$ & $\begin{array}{c}\text { E }<100 \mu \mathrm{m} \\
\text { E } 100-200 \mu \mathrm{m} \\
\text { E } 200-300 \mu \mathrm{m} \\
\text { E } 300-400 \mu \mathrm{m} \\
\text { E } 400-500 \mu \mathrm{m} \\
\text { E }>500 \mu \mathrm{m}\end{array}$ & $\begin{array}{c}2 \\
6 \\
9 \\
13 \\
17 \\
15 \\
\end{array}$ & $\begin{array}{l}0.005 \\
0.011 \\
0.016 \\
0.019 \\
0.029 \\
0.019\end{array}$ \\
\hline
\end{tabular}


The surface area measured in samples L2 and E2 after the agglomeration process is surprisingly low if the increase in carbon content of the agglomerated samples is considered. These low values are due to the blocking of pores entrance by some remaining oil not completely removed after the agglomeration process, as demonstrated in the previous work (Rubio et al. 2008). In that work it was observed that the remaining oil is burned off by heating at $500^{\circ} \mathrm{C}$, thus it can be easily removed during the activation process. The agglomerated and activated samples (L2A and E2A) show a significant increase in the surface area that is, however, attributable not only to the pores entrance opening, but mainly to the enlargement of the existing pores. There exists a great difference between the areas of L2A and E2A. As discussed previously, under the steam activation conditions Escucha samples are more reactive than Lada samples. A possible explanation is presence in Escucha samples of a higher amount of $\mathrm{Fe}, \mathrm{K}, \mathrm{Na}$ and $\mathrm{Ca}$ compounds which can act as catalysts. This observation is in agreement with the findings of $\mathrm{Lu}$ et al. (2010). Following these authors, Na-K-Ca and Na$\mathrm{K}-\mathrm{Fe}$ associated to carbon particles had catalytic effects on the development of the surface area of the carbon under activation. They also observed that the higher the concentration of the catalytic compounds, the more significant effects they had on the development of the surface areas.

The areas of the activated samples, not previously agglomerated (L1A and E1A), are lower, as corresponds to their lower carbon content. In this case, the surface area of E1A is lower than that of L1A, but their respective carbon contents must again be considered ( $6 \%$ and $24 \%$ respectively).

\subsection{NO removal}

The variation in NO conversion with the exposure time of Lada and Escucha samples obtained by sieving is shown in Figures 2 and 3.

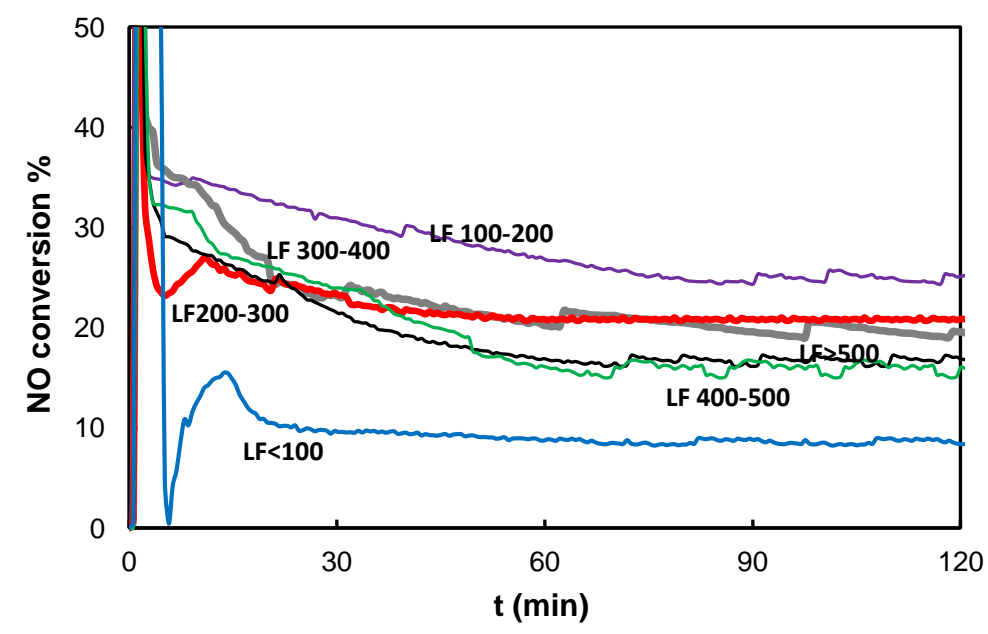

Fig. 2. NO conversion curves of Lada sieved fractions (gas conditions: $150{ }^{\circ} \mathrm{C}, 1000 \mu \mathrm{L} / \mathrm{L} \mathrm{NO}, 60 \mathrm{~mL} / \mathrm{L} \mathrm{O}_{2}, 1200$ $\mu \mathrm{L} / \mathrm{L} \mathrm{NH}$, Ar as balance)

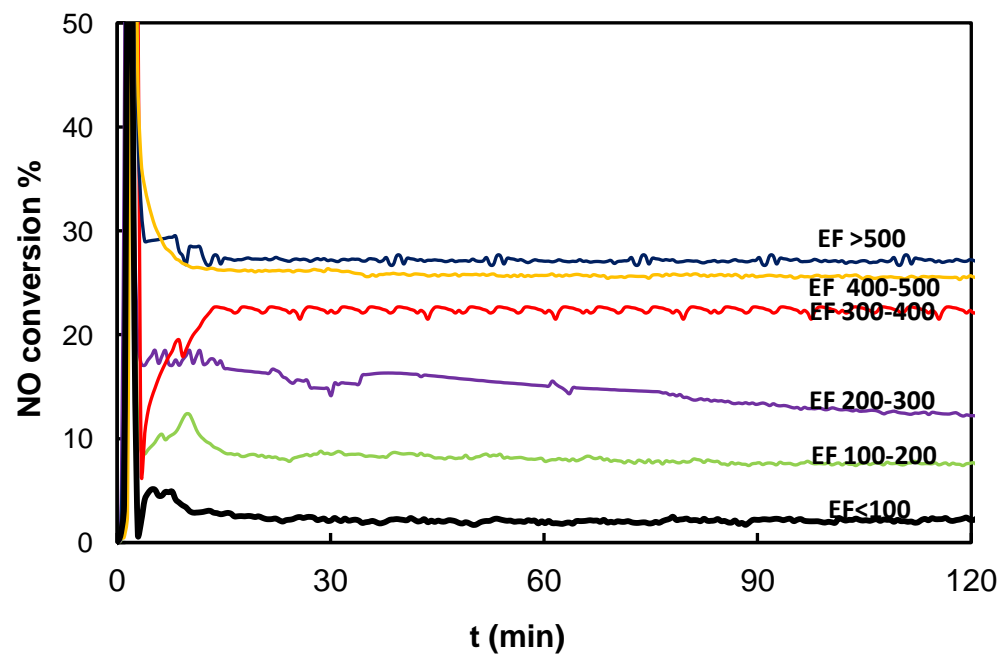

Fig.3. $\quad \mathrm{NO}$ conversion curves of Escucha sieved fractions (gas conditions: $150{ }^{\circ} \mathrm{C}, 1000 \mu \mathrm{L} / \mathrm{L} \mathrm{NO}, 60 \mathrm{~mL} / \mathrm{L} \mathrm{O}_{2}$, $1200 \mu \mathrm{L} / \mathrm{L} \mathrm{NH}_{3}$, Ar as balance) 
The breakthrough of NO occurs in the first 10 min, but it needs more than $1 \mathrm{~h}$ until the steady state prevails. This steady state is maintained for $20 \mathrm{~h}$ (the usual reaction time used in the experiments was $20 \mathrm{~h}$, but in some cases the reaction was continued for 250 $\mathrm{h}$ with the same reduction rate). Before the steady state is reached, partial reduction of $\mathrm{NO}$ to $\mathrm{N}_{2} \mathrm{O}$ is observed, being the lowest values of selectivity to $\mathrm{N}_{2}$ about $70 \%$. However, once the steady state is achieved, no emissions of $\mathrm{N}_{2} \mathrm{O}$ are detected, and the selectivity to $\mathrm{N}_{2}$ is $100 \%$. In presence of $\mathrm{O}_{2}$ and under the studied conditions $90 \mu \mathrm{L} / \mathrm{L} /-100 \mu \mathrm{L} / \mathrm{L}$ of the inlet $\mathrm{NO}$ was oxidised to $\mathrm{NO}_{2}$. The concentration of this $\mathrm{NO}_{2}$ was followed in several experiments, as shown in Figure 5.

NO removal of Escucha fractions increases as the particle size does, but it is not the case of Lada fractions. This is attributable to the different carbon content of the fractions, carbon concentrates in the coarser particles in Esucha FA but not in those of Lada. No correlation between the NO removal capacity of the size separated fractions and their ash composition was found within each series. As an example, the amount of NO removed by each series of fractions after $2 \mathrm{~h}$ of reaction is plotted in Figure 4 against their content in $\mathrm{Fe}$, expressed as $W \mathrm{Fe}_{203} \mathrm{x} 100$ and determined by ICP. It is clear there is a lack of relationship between removed $\mathrm{NO}$ and Fe content of the size separated fractions. Similar lack of correlation was found for the other mineral components.

When Figure 2 and Figure 3 are compared and their respective carbon content is considered, better performance for Escucha samples is observed, even for $\mathrm{Dp}<300 \mu \mathrm{m}$. For instance, the NO conversion reached with LF $100-200 \mu \mathrm{m}$ at the steady state is nearly $30 \%$, whereas EF $100 \mu \mathrm{m}-200 \mu \mathrm{m}$ removes only $8 \%$ of NO, however, their carbon content is $7 \%$ and that of LF $100-200 \mu \mathrm{m}$ is $47 \%$. Fractions of Dp $>300 \mu \mathrm{m}$ from both FA have a very similar carbon content, but the NO conversion reached by Escucha fractions is higher.

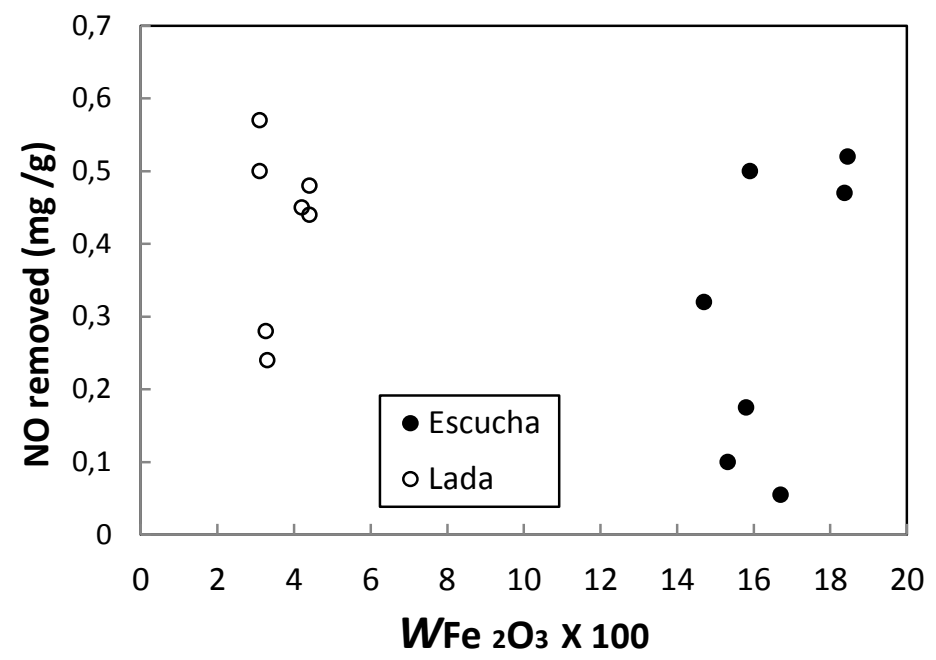

Fig. 4. Relationship between Fe content (expressed as $w_{\mathrm{Fe} 2 \mathrm{O}}$ obtained by ICP) and the amount of $\mathrm{NO}$ removed after $2 h$ for the samples studied

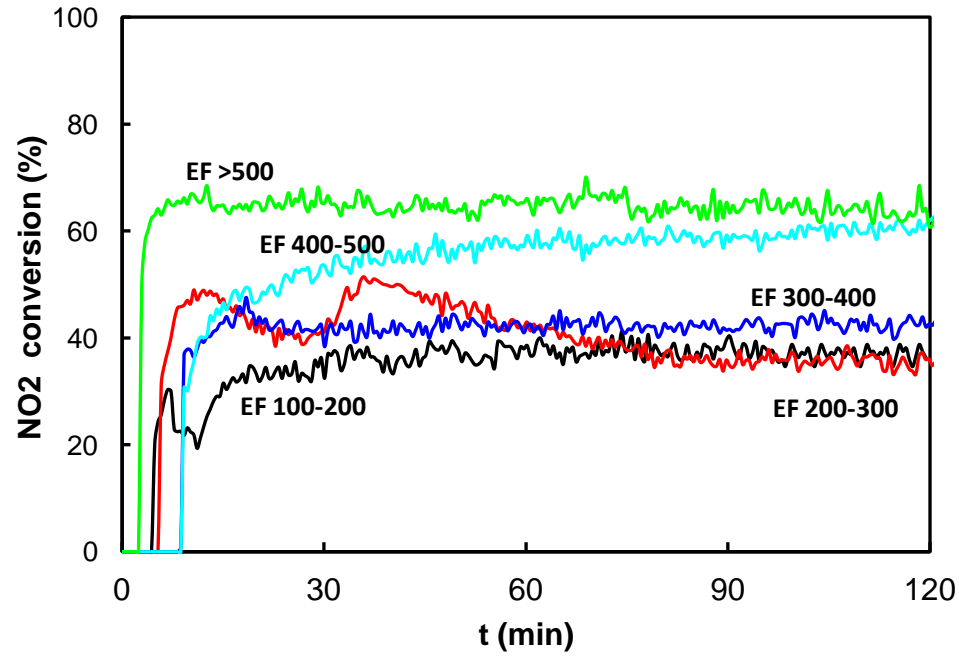

Fig. 5. $\mathrm{NO}_{2}$ conversion curves of Escucha sieved fractions (gas conditions: $150{ }^{\circ} \mathrm{C}, 1000 \mu \mathrm{L} / \mathrm{L} \mathrm{NO}, 60 \mathrm{~mL} / \mathrm{L} \mathrm{O}_{2}$, $1200 \mu \mathrm{L} / \mathrm{L} \mathrm{NH}_{3}$, Ar as balance) 
As said above, in presence of $\mathrm{O}_{2}$ and under the studied conditions, $90 \mu \mathrm{L} / \mathrm{L} /-100 \mu \mathrm{L} / \mathrm{L}$ of the inlet $\mathrm{NO}$ was oxidised to $\mathrm{NO}_{2}$. It can be seen in Figure 5 that the $\mathrm{NO}_{2}$ conversion over Escucha fractions is higher in all cases than the NO conversion, shown in Figure 3, indicating that $\mathrm{NO}_{2}$ competes with $\mathrm{NO}$ for the reaction sites. In fact, the order or activity of Escucha fractions is the same as for $\mathrm{NO}$ : coarser particles $(>300 \mu \mathrm{m})$ show higher $\mathrm{NO}_{2}$ conversion.

Differences in activity between Lada and Escucha fractions mentioned above are more evident in agglomerated and activated samples of both FA whose NO removal capacity versus time is shown in Figure 6. E2A shows a NO conversion of $48 \%$ but L2A reaches only $33 \%$. Samples E1, E2 and E1A show also similar or higher NO removal capacity than L1, L2 and L2A, despite their lower carbon content.
It is also interesting to point out two facts arising from these results: i) very poor performance of agglomerated samples L2 and E2 that can be attributed to the negative effect of remaining oil, and ii) similar or even lower NO removal capacity of samples L1A and E1A (obtained by activation of nonagglomerated precursors) compared to their precursors L1 and E1 in spite of the higher surface area of the former. The explanation in the case of Escucha samples can be found in a low carbon content of activated sample E1A due to a higher level of burn off reached as well as a low carbon content of its precursor E1. In the case of L1A a decrease in carbon content by burn off is minimal (from $26 \%$ to $24 \%$ ), so the explanation in this case may be related to a poorly developed surface chemistry or textural properties.

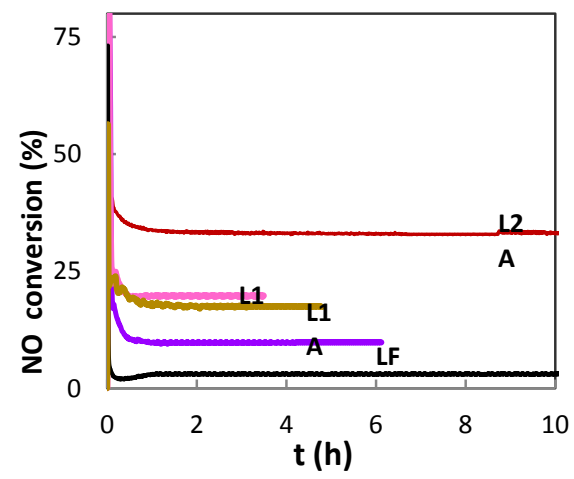

(a)

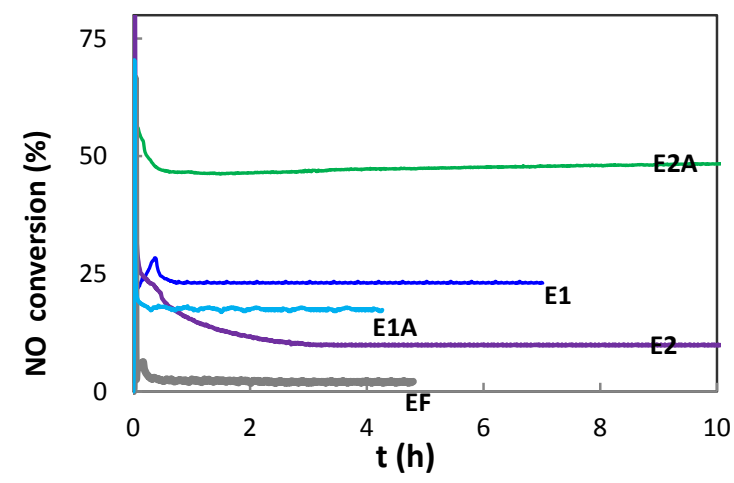

(b)

Fig. 6. NO conversion curves of Lada (a) and Escucha (b) raw and treated samples. Gas conditions: $150{ }^{\circ} \mathrm{C}$, $1000 \mu \mathrm{L} / \mathrm{L} \mathrm{NO}, 6 \% \mathrm{O}_{2}, 1200 \mu \mathrm{L} / \mathrm{L} \mathrm{NH}_{3}$, Ar as balance)

Figure 7 illustrates the relationship between the amount of NO removed after two hours of reaction and the carbon content of all studied CECFA. A higher performance of Escucha CECFA for the same carbon content can be observed that as discussed above is not directly attributable to the differences in a mineral content. Samples L2 and E2, obtained by oil agglomeration but not activated, fall out of this trend, because of the blocking of pores entrance produced by the oil remaining from the agglomeration process, as commented above.

In Figure 8 the amount of NO removed by the studied samples after two hours of reaction is plotted against their BET surface area. From this Figure it could be inferred that the NO removal capacity of both activated and non-activated samples show a direct dependence of surface area. However, it should be noticed that the surface areas of non-activated samples are directly related to their carbon content (it is generally agreed that mineral matter contribution to surface areas is only $0.7-0.8 \mathrm{~m}^{2} / \mathrm{g}$ ) (Kulaots et al. 2004). On the other hand, the porosity and, consequently, the surface area of the activated samples have been developed during the activation process, but it is surprising that two activated samples (L1A and E1A) remove less NO than some non-activated samples. This fact can be again explained taking into account the carbon content of samples E1A and L1A (6 and 24\% respectively) and the coarser fractions obtained by sieving (above 25\%) suggest that the surface area of activated samples could not be fully utilized.

The influence of the surface area on the NO removal can more clearly observed comparing samples E2A and L2A. These samples have a similar carbon content, and in this case the amount of $\mathrm{NO}$ removed by sample E2A (surface area $395 \mathrm{~m}^{2} / \mathrm{g}$ ) is twice the amount of NO removed by sample L2A (surface area $217 \mathrm{~m}^{2} / \mathrm{g}$ ). The higher surface area and the level of burn off shown by E2A indicate the higher reactivity of the unburned coal coming from Escucha FA attributable to the lower rank of its parent coal and also to the presence of $\mathrm{Fe}, \mathrm{K}, \mathrm{Na}$ and $\mathrm{Ca}$ compounds, as previously discussed. 


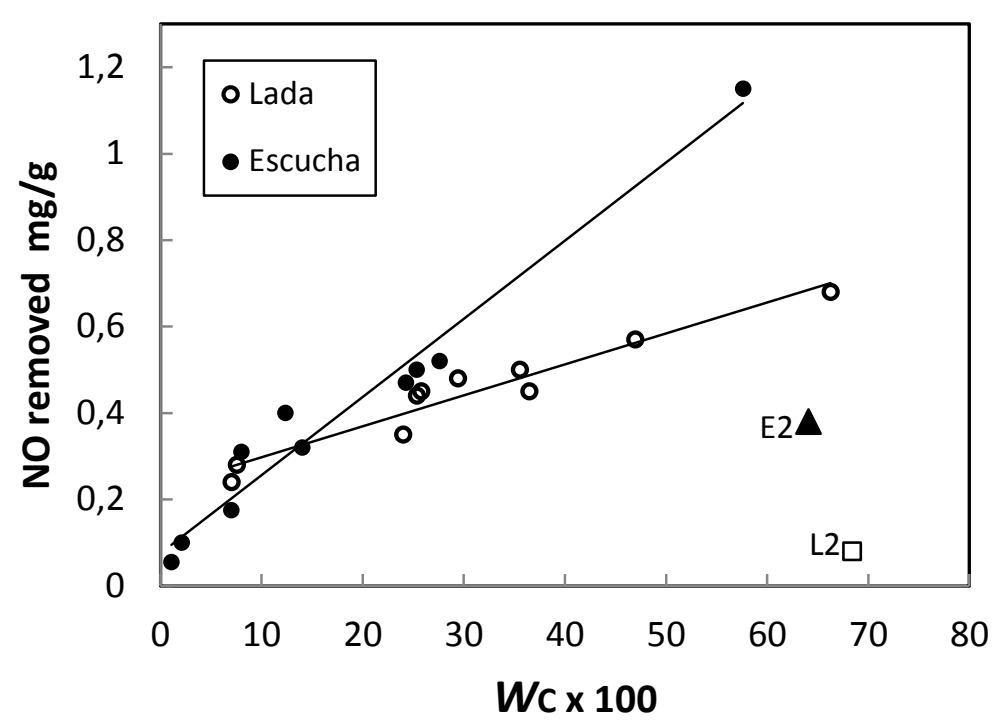

Fig. 7. Relationship between carbon content and the amount of NO removed by the obtained CECFAs (2 h of reaction, $2 g$ of sample)

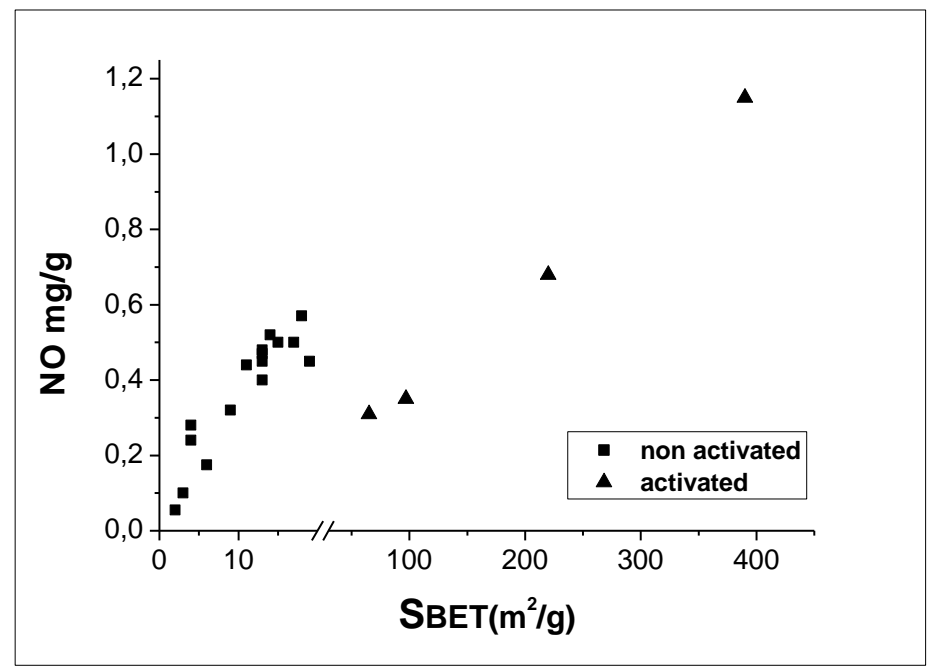

Fig. 8 .

Relationship between the amount of removed NO and BET surface of CECFAs ( 2 h of reaction, $2 g$ of sample)

\subsection{Environmental impact assessment during CECFA production and utilization}

The environmental indicators calculated for CEFCA production (Table7) correspond to the following stages: sieving, agglomeration and steam activation, excluding FA transportation. The environmental burden for steel and ammonia production is not considered since this point has been analysed in several life cycle studies in the literature (Bárzaga-Castellanos et al. 1999; Azapagic 1999).

To compare selective catalytic reduction of NO with the data found in the literature, we have calculated all the parameters per kilogram of removed NO. In the work presented here the longest operating period of testing was $250 \mathrm{~h}$, and in this time the reduction rate was maintained without variations, therefore the real operating time would be longer. However, the calculation of the environmental indicator has been done in accordance with $250 \mathrm{~h}$ of NO removal.

No electrical demand has been assumed for CEFCA utilization in low temperature SCR of NO, since the temperature used in the experiments $\left(150^{\circ} \mathrm{C}\right)$ is close to that of tail end gases, and there is no need for reheating.

No additional solid waste is produced by sieving. Moreover, refused ashes are free from unburned coal and become marketable for the cement industry.

The electrical demand for agglomerated and activated CECFA is the sum of: sieving (0.003 Mwh/kg NOx), agglomeration (0.002 Mwh/kg NO) and activation (0.53 Mwh/kg NO). Water consumption comes from the agglomeration stage: $270 \mathrm{~L} / \mathrm{kg} \mathrm{NO}$ and activation stage: $104 \mathrm{~L} / \mathrm{kg} \mathrm{NO}$. Wastewater and solid waste come from an 
agglomeration stage. Actually wastewater is composed of water $+4 \%$ oil + refused fly ashes.

Washing with ethanol, perchloroethylene and ethyl ether of the agglomerates is performed only at a laboratory scale for obtaining analytical data, but it could be avoided at an industrial scale, because the remaining oil is gasified during the steam activation stage.

Within the European Union, emissions from large combustion plants are regulated under the Integrated Pollution Prevention and Control (IPPC) Directive 96/611EC and the Large Combustion Plants (LCP) Directive 2001/80/EC. The Directive sets the Emission Limit Values (ELVs) for $\mathrm{SO}_{2}$, NOx and dust into the air from combustion plants with a rated thermal input equal to or exceeding $50 \mathrm{MW}$. From
2008 the NOx limit value for $>500 \mathrm{MWh}$ plants burning solid fuels is $500 \mathrm{mg} / \mathrm{Nm}^{3}$.

Following this legislation and the NO reduction level reached by the CECFA samples studied (28\% for sieved samples and $48 \%$ for agglomerated and activated samples) the current ELVs for NOx would be reached only if the NO inlet were not higher than $600 \mu \mathrm{L} / \mathrm{L}$ for the first type of samples, and $800 \mu \mathrm{L} / \mathrm{L}$ for the second type.

In the work presented here an excess of ammonia has been used to ensure its availability in the surface of the carbon, but it has been shown (Lázaro et al. 2006) that for this type of materials a ratio $\mathrm{NH}_{3} / \mathrm{NO}$ of 0.7 is sufficient to perform the $\mathrm{NO}$ reduction, therefore this ratio has been used in the calculation of ammonia slip. Even using this ratio, the ammonia slip is an important environmental burden.

Environmental impact assessment during CECFA production and its further utilization in lowtemperature removal of $N O$ from flue gases referred to $1 \mathrm{~kg}$ of removed $\mathrm{NO}$, and $250 \mathrm{~h}$ operating period $\left(1000 \mu \mathrm{L} / \mathrm{L} \mathrm{NO}\right.$ inlet, $\mathrm{NH}_{3} / \mathrm{NO}$ ratio $\left.0.7,150^{\circ} \mathrm{C}\right)$

\begin{tabular}{|c|c|c|c|c|}
\hline & \multicolumn{2}{|c|}{$\begin{array}{l}\text { CECFA obtained by } \\
\text { sieving }\end{array}$} & \multicolumn{2}{|c|}{$\begin{array}{c}\text { CECFA obtained by } \\
\text { sieving+ agglomeration }+ \text { activation }\end{array}$} \\
\hline & $\begin{array}{l}\text { Production } \\
\text { process }\end{array}$ & $\begin{array}{l}\text { Utilization in } \\
\text { low temperature } \\
\text { NO removal } \\
\text { (28\% reduction } \\
\text { rate) }\end{array}$ & $\begin{array}{c}\text { Production } \\
\text { process }\end{array}$ & $\begin{array}{c}\text { Utilization in } \\
\text { low temperature } \\
\text { NO removal } \\
\text { (48\% reduction } \\
\text { rate) }\end{array}$ \\
\hline Electrical energy demand (Mwh) & 0.004 & - & 0.53 & - \\
\hline Water consumption $\left(\mathrm{m}^{3}\right)$ & - & - & 1.55 & - \\
\hline $\mathrm{CO}_{2}$ emissions (direct, $\mathrm{kg}$ ) & - & - & 2.21 & - \\
\hline Ammonia slip (kg) & - & 0.85 & - & 0.21 \\
\hline NO outlet $(\mathrm{kg})$ & - & 2.35 & - & 1.09 \\
\hline Wastewater $\left(\mathrm{m}^{3}\right)$ & - & - & 1.45 & - \\
\hline Solid wastes (kg) & - & 14.32 & - & 8.69 \\
\hline
\end{tabular}

\section{Conclusions}

Carbon enriched fractions coming from pulverized coal fly ashes can be adequate precursors to obtain the carbon showing good performance after proper activation in the low temperature nitric oxide reduction with ammonia from flue gases.

Under the conditions of the study the fractions obtained by sieving show NO reduction levels varying from 3 to $29 \%$, depending on their carbon content. Comparing samples with the same carbon content, the fractions from Escucha FA show higher NO removal capacity than Lada FA..

The fractions L2 and E2 obtained after sieving and oil agglomeration show the highest carbon content (68\% and $64 \%$ mass fraction respectively) but their NO removal capacity is low, $0.1 \mathrm{mg} / \mathrm{g}$ and $0.35 \mathrm{mg} / \mathrm{g}$ respectively, because of the blocking action of oil on their porous texture. The significant NO reduction reached by activated samples $\mathrm{L} 2 \mathrm{~A}$ and E2A, $0.72 \mathrm{mg} / \mathrm{g}$ and $1.18 \mathrm{mg} / \mathrm{g}$ respectively, can be attributed to the development of their surface area during the activation process. The higher surface area of sample E2A $\left(395 \mathrm{~m}^{2} / \mathrm{g}\right)$ with respect to L2A (217 $\mathrm{m}^{2} / \mathrm{g}$ ) is the main reason for its superior NO removal capacity. The higher surface area developed by Escucha sample E2A in the activation process can be attributed to: 1) the lower rank of its parent coal (subbituminous and lignite) that makes unburned coal of Escucha FA more reactive compared to that of Lada FA which comes from anthracite, and 2) its high content in several metallic species (Fe, Ca, K) of Escucha FA, which promotes the carbon gasification during the activation process, and therefore the development of surface area. These metallic species, however, do not seem to have influence in the process itself of NO reduction with ammonia over the carbon surface in the samples studied.

In view of the obtained results, it can be concluded that carbon content, surface area and parent coal type are the main parameters that influence the NO removal capacity of the carbon-enriched coal fly ash at the studied conditions.

The main environmental burden of the overall process comes from the electrical demand for the activation stage, as well as from the ammonia slip. The NOx emissions could be kept under the required limits proposed by the LCP Directive 2001/80/EC if the flue gas contains less than $800 \mu \mathrm{L} / \mathrm{L}$ of NOx. 


\section{Acknowledgements}

The Spanish Ministry of Science and Innovation and the European Community (European Regional Development Fund) provided financial support for this work (Project No. CTM2004- 04252C02).

The authors wish also to thank Dr Tarazona and coworkers for performing oil agglomeration.

\section{References}

AHMARUZZAMAN, M. A review on the utilization of fly ash. Progress in Energy and Combustion Science 2010, Vol. 36, pp. 327-363. http://dx.doi.org/10.1016/j.pecs.2009.11.003

ALONSO M.I., VALDES A.F., MARTINEZTARAZONA, R.M., GARCIA, A.B. Coal recovery from coal fines clearing wastes by agglomeration with vegetable oils: effects of oil type and concentration, Fuel, 1999, Vol. 78, pp. 753- 759. http://dx.doi.org/10.1016/S00162361(98)00218-X

ARENILLAS, A., SMITH, K.M., DRAGE, T.C., SNAPE, C.E. $\mathrm{CO}_{2}$ capture using some fly ash-derived carbon materials. Fuel 2005, Vol. 84, pp. 2204-2210. http://dx.doi.org/10.1016/j.fuel.2005.04.003

AZAPAGIC, A. Life cycle assessment and its application to process selection, design and optimization. Chemical Engineering Journal 1999, Vol. 73, pp.1-21. http://dx.doi.org/10.1016/S1385-8947(99)00042-X

BARZAGA-CASTELLANOS, L., NEUFERT, R., KAYSER, G., MARKERT, B. Lyffe Cycle Assessment of the Seletive Catalyti Reduction Process for Power Plants. Int. J. LCA 1999, Vol. 4, pp. 329-338. http://dx.doi.org/10.1007/BF02978523

CHA, J.S., CHOI, J.C., KO, J.H., PARK, Y.K., PARK, S.H., JEONG, K.E., KIM, S-S., JONG-KI JEONG, $\mathrm{J}-\mathrm{K}$. The low-temperature SCR of NO over rice straw and sewage sludge derived char. Chemical Engineering Journal 2010, Vol. 156, pp. 321-327. http://dx.doi.org/10.1016/j.cej.2009.10.027

DAVINI, P. Flue gas treatment by activated carbon obtained from oil-fired fly ash. Carbon 2002, Vol. 40, pp. 1973-1979. 6223(02)00049-0

DOMAZETIS, G., RAOARUN, M., JAMES, B.D., JOHN LIESEGANG, J. Molecular modeling and experimental studies on steam gasification of low-rank coals catalyzed by iron species. Appl. Catal. A: Gen. 2008, Vol. 340 , $\mathrm{pp}$

$105-118$ http://dx.doi.org/10.1016/j.apcata.2008.01.037

GÁLVEZ, M.E., BOYANO, A., MOLINER, R., LÁZARO, M.J. Low-cost carbon-based briquettes for the reduction of NO emissions: Optimal preparation procedure and influence in operating conditions. Journal of Analytical and Applied Pyrolysis 2010, Vol. 88, pp. 80-90. http://dx.doi.org/10.1016/j.jaap.2010.02.010

HJALMARSSON, A. K. 1990. NOx Control Technologies for Coal Combustion. IEA Coal Research. London. ISBN 92-9029-177-X

IZQUIERDO, M.T., RUBIO, B., MAYORAL, M. C., BONA, M.T., ANDRÉS, J.M.. Denitrification of stack gases in the presence of low-rank coal-based carbons activated with steam. Energy \& Fuels 2007, Vol. 21, pp. 2033-2037. http://dx.doi.org/10.1021/ef0605571

IZQUIERDO, M.T., RUBIO, B. Carbon-enriched coal fly ash as a precursor of activated carbons for $\mathrm{SO}_{2}$ removal.
J. Hazard. Mater. 2008, Vol. 155, pp. 199-205. http://dx.doi.org/10.1016/j.jhazmat.2007.11.047

IZQUIERDO, M.T., RUBIO, B. 2009. Flue gases: Research, Technology and Economics. Control of NOx emissions from energy production. Nova Science Publisher Inc. New York, pp. 203-234. ISBN 978-1-60692-449-5

KÜLAOTS, I., HURT, R.H., SUUBERG, E.M. Size distribution of unburned carbon in coal fly ash and its implications. Fuel 2004, Vol. 83, pp. 223-230. http://dx.doi.org/10.1016/S0016-2361(03)00255-2

LÁZARO, M.J., GÁLVEZ, M.E., RUIZ, C., JUAN, R., MOLINER, R. Vanadium loaded carbon-based catalysts for the reduction of nitric oxide. Applied Catalysis B:

Environmental 2006, Vol. 68, pp. 130-138. http://dx.doi.org/10.1016/j.apcatb.2006.07.025

LINDON, K.A. 2001. The Properties and Use of Coal Fly Ash. Thomas Telford. London. ISBN 0-7277-3015-0. http://dx.doi.org/10.1680/pauocfa.30152

LU, G.Q., DO, D.D.. Adsorption properties of fly ash particles for NOx removal from flue gases, Fuel Process. Technol. 1991, Vol. 27, pp. 95-107. http://dx.doi.org/10.1016/0378-3820(91)90011-Z

LU, Z., MAROTO-VALER, M.M., SCHOBERT, H.H. Catalytic effects of inorganic compounds on the development of surface areas of fly ash carbon during steam activation.

Fuel 2010, Vol. 89, pp. 3436-3441. http://dx.doi.org/10.1016/j.fuel.2010.05.024

MAROTO-VALER, M.M., ZHANG, Y., GRANITE, E.J., TANG, Z., PENNLINE, H.W. Effect of porous structure and surface functionality on the mercury capacity of a fly ash carbon and its activated samples, Fuel 2005, Vol. 84, pp. 911-916. http://dx.doi.org/10.1016/j.fuel.2004.07.005

MAROTO-VALER, M., LU, Z., ZHANG, Y., TANG, Z.M. Sorbents for $\mathrm{CO}_{2}$ capture from high carbon fly ashes. Waste Management 2008, Vol. 28, pp. 2320-2328. http://dx.doi.org/10.1016/j.wasman.2007.10.012

MORENO,N., QUEROL, X., ANDRÉS, J.M., STANTON, K., TOWLER, M., NUGTEREN, H, JANSSEN-JURKOVICOVÁ, M., JONES, R. Physicochemical characteristics of European pulverized coal combustion fly ashes. Fuel 2005, Vol. 84, pp. 1351-1363. http://dx.doi.org/10.1016/j.fuel.2004.06.038

NAKAJIMA, F., HAMADA, I. The state-of-the-art technology of NOx control. Catal. Today 1996, Vol. 29, pp. 109-115. http://dx.doi.org/10.1016/0920-5861(95)00288-X

NOLLET, H., ROELS, M., LUTGEN, P., VAN DER MEEREN, P., VERSTRAETE, W. Removal of PCBs from wastewater using fly ash. Chemosphere 2003, Vol. 53, pp. 655-665. http://dx.doi.org/10.1016/S0045-6535(03)00517-4

RASTOGI, K., SAHU, J.N., MEIKAP, B.C., BISWAS, N.B. Removal of methylene blue from wastewater using fly ash an adsorbent by hydrocyclone. J. of Hazard. Mater. 2008, Vol. 158, pp.531-540. http://dx.doi.org/10.1016/j.jhazmat.2008.01.105

RICHTER, E., SCHMIDT, H-J., SCHECKER, H.G. Adsorption and Catalytic Reactions of $\mathrm{NO}$ and $\mathrm{NH}_{3}$ on Activated Carbon. Chem. Eng. Technol. 1990, Vol. 13, pp. 332-340. http://dx.doi.org/10.1002/ceat.270130146

RUBEL, A., ANDREWS, R., GONZALEZ, R., GROPPO, J., ROBL, T. Adsorption of $\mathrm{Hg}$ and NOx on coal by-products, Fuel 2005, Vol. 84, pp. 911-916. http://dx.doi.org/10.1016/j.fuel.2005.01.006

RUBIO, B., IZQUIERDO, M.T., MAYORAL, M.C., BONA, M.T., ANDRES, J.M. Unburnt carbon from coal fly ashes as a precursor of activated carbon for nitric oxide removal. J.of Hazard. Mater. 2007, Vol. 143, pp. 561-566. 
RUBIO, B., IZQUIERDO, M.T., MAYORAL, M.C., BONA, M.T., MARTINEZ-TARAZONA, R.M., Preparation and characterization of carbon-enriched coal fly ash. J. Environ. Manage. 2008, Vol. 88, pp. 1562-1570. http://dx.doi.org/10.1016/j.jenvman.2007.07.027

WANG, S., VIRARAGHAVAN, T. Wastewater sludge conditioning by fly ash. Waste Management 1998, Vol. 17, pp. 443-450. http://dx.doi.org/10.1016/S0956053X(97)10050-2

WANG, S., WU, H. Environmental-benign utilization of fly ash as low-cost adsorbents. Journal of Hazardous Materials 2006, Vol. 136, pp. 482-501. http://dx.doi.org/10.1016/j.jhazmat.2006.01.067

YU, J., TIAN, F.-J., CHOW, M.C., MCKENZIE, L.J., LI, C.-Z. Effect of iron on the gasification of Victorian brown coal with steam: enhancement of hydrogen production. Fuel 2006, Vol. 85, pp. 127-133. http://dx.doi.org/10.1016/j.fuel.2005.05.026
Dr. Begoña Rubio. Tenured Scientific Researcher . Department of Energy and Environment, Instituto de Carboquímica. ICB-CSIC. Zaragoza, Spain.

Main research area: carbon materials for technological applications, waste recycling, $\mathrm{Hg}$ capture

Address: $\quad$ c/Miguel Luesma Castán, 4 50018Zaragoza (Spain)

Tel.: +34-976-733977

E-mail: brubio@icb.csic.es

Dr. Maria Teresa Izquierdo. Tenured Scientific Researcher . Department of Energy and Environment, Instituto de Carboquímica. ICB-CSIC. Zaragoza, Spain

Main research area: carbon materials for technological applications, waste recycling, $\mathrm{Hg}$ capture, VOCs capture

Address: $\quad$ c/Miguel Luesma Castán, 4 50018-

Tel. $\quad$ Zaragoza (Spain)

E-mail: $\quad$ mizq@icb.csic.es

\title{
Azoto oksido šalinimas iš dūmų dujų naudojant anglimi praturtintus pelenus
}

\section{Begoña Rubio, MariaTeresa Izquierdo}

Energijos ir aplinkos departamentas, Carboquimica institutas, Ispanija

\author{
(gauta 2012 m. lapkričio mèn., priimta spaudai 2013 m. kovo mèn.)
}

Šio darbo tikslas - ivvertinti aktyvuotos ir neaktyvuotos anglies savybes, išgautas iš anglimi praturtintų pelenu susidarius dviem skirtingoms energijos stotims tam, kad šie pelenai būtu panaudoti NO pašalinti iš dūmtraukio dujų. Lyginant skirtingus variantus su tuo pačiu anglies kiekiu, nustatyta, kad iš Escucha naudojamu pelenu NO šalinimo potencialas didesnis. Gauti rezultatai rodo, kad pagrindiniai veiksniai, lemiantys NO šalinimo galimybes, yra šie: anglies dalis, paviršiaus plotas ir pirminès anglies rūšis. 